\title{
What Drives the Urban Wage Premium? Evidence along the Wage Distribution
}

\author{
Alessia Matano ${ }^{1}$ and Paolo Naticchioni ${ }^{2}$
}

July 2015

\begin{abstract}
This paper aims at disentangling the role played by different explanations on the urban wage premium along the wage distribution. We analyze the wage dynamics of migrants from lower to higher density areas in Italy, using quantile regressions and individual data. The results show that unskilled workers benefit more from a wage premium accruing over time, while skilled workers enjoy a wage premium when they migrate as well as a wage increase over time. Further, we find that for unskilled workers the wage growth over time is mainly due to human capital accumulation in line with the "learning" hypothesis, while for skilled workers the wage growth is mainly explained by the "coordination" hypothesis, i.e., cities enhance the probability of better matches between workers and firms.
\end{abstract}

JEL Classification: J31, J61, R23.

Keywords: Urban Wage Premium, Human Capital, Spatial Sorting, Wage Distribution, Quantile Fixed Effects.

\footnotetext{
** We thank the research partnership between ISFOL - Area Mercato del Lavoro (Rome) - and Dipartimento di Scienze Sociali ed Economiche- University of Rome "La Sapienza" - for access to the databases. We are very grateful to Roger Koenker and Ivan Canay for suggestions concerning the implementation of the quantile fixed effect procedures, and to Gianmarco Ottaviano and two anonymous referees for helpful comments. Our thanks also go to the participants in the AIEL conference (Milan, 2011, Naple 2012), ERSA conference (Barcelona, 2011), UB seminar (Barcelona, 2011), Crenos seminar (Cagliari, 2012), EALE conference (Bonn, 2012), SAEe conference (Vigo, 2012), ICEEE conference (Genoa, 2013) and OFCE Science Po seminar (Nice, 2014) for useful suggestions. Alessia Matano expresses her gratitude for the financial support received from the Spanish Ministry of Economy and Competitiveness through the project ECO2013-41022-R.

${ }^{1}$ Alessia Matano, University of Barcelona UB, AQR-IREA, University of Rome "La Sapienza", Dipartimento di Scienze Sociali ed Economiche. Email: amatano@ub.edu.

2 Corresponding Author: Paolo Naticchioni, University of Roma Tre, IZA. Email: p.naticchioni@gmail.com.
} 


\section{Introduction}

The existence and extent of the urban wage premium have been widely investigated in the spatial economic literature, and various different theories have been proposed. The most widely accepted explanation refers to urbanization externalities in terms of reduced transport costs, technology and knowledge spillovers, cheaper inputs, proximity to consumers and market potential (Glaeser, 1998, Kim, 1987, Ciccone and Hall, 1996, Hanson, 2005). According to this theoretical framework, workers moving to cities should immediately experience wage level increases, while those leaving cities should experience wage losses (wage level effect). More recently, a "learning" explanation has been proposed, i.e. in cities human capital accumulation is faster (Glaeser, 1999, Moretti, 2004, Glaeser and Resseger, 2010). In this framework, workers moving to cities will only experience wage increases over time (wage growth effect), while those leaving cities will not necessarily suffer wage losses. Another explanation that entails the possibility of a wage growth effect being generated is the "coordination" hypothesis, since cities enhance the probability of a better match between workers and firms, and this probability increases with the time spent in cities (Kim, 1990, Helsley and Strange, 1990, Yankow, 2006). Furthermore, the literature has also pointed out the importance of controlling for the sorting of workers, since the urban wage premium could be the outcome, at least partially, of skilled workers being sorted into cities (Combes et al., 2008, Mion and Naticchioni, 2009, Matano and Naticchioni, 2012).

From the empirical point of view, the first paper that discussed and tested the role played by the different explanations is Glaeser and Mare (2001), which analyzes the determinants of the urban wage premium in the US. In particular, the authors analyze the migration flows from rural-to-urban areas (and vice versa), in order to disentangle the 
wage growth effect from the wage level effect. Glaeser and Maré (2001) also perform fixed effects estimates to control for the sorting of workers. Their results show that a nonnegligible part of the urban wage premium accrues to workers over time and is retained when they leave cities, in line with the wage growth explanation. Nonetheless, the authors also find evidence of the wage level effect.

More recently, other papers have extended the analysis of Glaeser and Maré (2001) to investigate further the determinants of wage growth in cities, focusing on the within- and between-jobs wage growth components which represent a proxy of the "learning" and “coordination" hypothesis (Yankow, 2006, Wheeler, 2006, Baum-Snow and Pavan, 2012).

The original contribution offered by this paper lies in extending to the whole wage distribution the analysis of the role played by the different theoretical explanations in accounting for the urban wage premium, which represents an unexplored field of research in the spatial economic literature, to the best of our knowledge. More specifically, we investigate whether the extent of the wage level and wage growth effects is different for skilled and unskilled workers. We refer to skilled workers as those located at the upper tail of the wage distribution and to unskilled workers as those located at the lower tail of the wage distribution. ${ }^{3}$ Another original contribution of the paper relies on the investigation of the drivers of the wage growth effect along the wage distribution.

We make use of the Italian employer-employee INPS (the Italian Social Security Institute) database, from 1986-2003. In the first part of the paper we analyze the wage dynamics of migrants from lower to higher, and from higher to lower, density provinces,

\footnotetext{
${ }^{3}$ Note that in this paper we do not exploit direct measures of occupation to identify the skill level, since we rely on the wage percentiles. This is also due to the fact that in our dataset the occupation information is highly aggregated (blue $v s$ white collar workers).
} 
by means of a quantile regression approach. ${ }^{4}$ Moreover, since previous empirical studies showed that the sorting of workers captures a significant part of the impact of spatial externalities on wages, both at the conditional mean (Combes et al., 2008, Mion and Naticchioni, 2009) and along the wage distribution (Matano and Naticchioni, 2012), the analysis takes into account the workers' unobserved heterogeneity by carrying out quantile fixed-effect estimations.

Our analysis shows that for unskilled workers, i.e. those at the $10^{\text {th }}$ percentile, the wage premium takes place mainly over time, in line with the wage growth level effect. As for skilled workers, i.e. those at the $90^{\text {th }}$ percentile of the distribution, the wage level and the wage growth effects have a similar magnitude, suggesting that they are able to capture both the benefits of agglomeration economies and the dynamic gains accruing over time.

We also take into account the recent analysis presented in De la Roca and Puga (2013), who claim that even fixed effects estimates may be biased when dynamic effects are not considered. To capture these dynamics effects, De la Roca and Puga (2013) introduce in the estimation different experience variables, focusing on where experience has been acquired. Implementing a similar specification on the sample of young workers, we show that the estimates of the wage level and wage growth effects do not substantially change in comparison to baseline estimates, with the only difference being a slight reduction in the wage growth effect, especially for the upper tail of the wage distribution. Interestingly, we also find that while experience displays decreasing returns along the wage distribution, experience acquired in top cities (Rome and Milan) is associated to increasing returns along the distribution.

\footnotetext{
${ }^{4}$ Our results are also confirmed when using a dichotomic classification of Italian provinces, above and below the density median, similarly to Glaeser and Maré (2001). These estimates are available upon request.
} 
Since our analysis suggests that the wage growth effect plays a role for both skilled and unskilled workers, in the second part of the paper we focus on the drivers of the wage growth effect, i.e. on disentangling the "learning" from the "coordination" explanation. We consider the sample of migrants from lower to higher density provinces after migration, using quantile fixed effects regressions. As a proxy for between-jobs wage growth we use the job-change dummy (as in Baum-Snow and Pavan, 2012), while as a proxy for within-job wage growth we use the job tenure variable (Topel, 1991). Once controlled for sorting, our findings show that skilled workers benefit more from better matching opportunities in cities, enjoying greater returns to job changes. As for unskilled workers, they benefit more from higher human capital accumulation, i.e. greater returns to tenure, once in cities. Similar results are derived using the sample of stayers in low- and high-density provinces. This suggests that the wage dynamics detected for the migrants can be extended to different groups of workers in the economy, thereby reassuring about the possible endogeneity of the migration choices.

Our results clearly bring out the importance of investigating the determinants of the urban wage premium along the wage distribution, since the relevance of the different explanations differs between skilled and unskilled workers. Further, it is also worth stressing that taking into account the whole wage distribution affords new insights that prove more revealing than when conventional measures of skills are applied, such as education levels. ${ }^{5}$

The structure of the paper is as follows. In Section 2 we review the literature on the urban wage premium. In Section 3, we describe the data, define the spatial variable and

\footnotetext{
${ }^{5}$ According to the 1996 data of the European Community Household Panel, almost 50\% of Italian graduates were not employed in the top quartile of the wage distribution, and around $20 \%$ had a wage lower than the median. This suggests a substantial heterogeneity within education levels, heterogeneity that can be investigated by using quantile regressions.
} 
present some descriptive statistic, while Section 4 sets out the empirical analysis and discusses the main results. The conclusions are drawn in Section 5.

\section{Related Literature}

The explanations related to the urban wage premium have been broadly analysed by the literature. As stressed in the introduction, one of the seminal paper is Glaeser and Maré (2001), which makes use of US data (1990 census, National Longitudinal Survey of Youth NLSY- and Panel Study of Income Dynamics -PSID-) to analyze the migration flows from rural-to-urban areas (and vice versa), in order to distinguish the wage growth effect (interpreted as human capital accumulation) from the wage level effect (agglomeration economies). Their results show that the wage growth effect plays an important role. A similar finding is found by Lehmer and Möller (2010) for Germany: the urban wage premium is due more to a wage growth effect related to human capital accumulation than to a wage level effect, especially for more experienced workers.

Other related papers have investigated further the main finding emphasized by Glaeser and Maré (2001), i.e. the wage growth effect and its determinants. Using the NLSY data, Wheeler (2006) shows that, on average, wage growth tends to be positively associated with the size of the local market. Further, he also points out that faster wage growth is related to job changes rather than to within-job wage growth, supporting the coordination explanation. On the same topic, Yankow (2006) shows that there is no statistical difference between urban and non-urban workers in the average wage gain from a single job change. However, he finds evidence that in cities there is a significantly higher frequency of job changes, entailing a higher cumulative wage growth related to job changes. 
Baum-Snow and Pavan (2012) use the NLSY data for the US to develop a structural onthe-job-search model that includes all the relevant explanations that affect the urban wage premium (unobserved ability, search frictions, quality job matching, human capital accumulation and endogenous migration). They find out that human capital accumulation is more important among large and small cities, while wage level effects are more important among medium and small-sized cities. ${ }^{6}$

Another related paper is De la Roca and Puga (2013), who claim that fixed effects estimates may be biased when dynamic effects are not taken into account. Using administrative data for Spain, they estimate a wage regression where, apart from controlling for cities and individual fixed effects, they introduce various experience variables, i.e. proxy for dynamic gains, related to where experience has been acquired and where it has been used. They show that in bigger cities workers obtain an immediate static premium and accumulate more valuable experience, which persists after workers move elsewhere, and which is greater for workers with higher innate ability.

All these studies focus on the analysis of the determinants of the urban wage premium evaluated at the conditional mean. The original contribution of this paper is to extend the analysis along the whole wage distribution. Some papers have already focused on related, but different, distributional/inequality issues, using either aggregate data (Wheeler, 2004, Möller and Haas, 2003) or individual level data (Matano and Naticchioni, 2012, Combes et al., 2012). None of them, however, has focused on disentangling the static and dynamic components of the urban wage premium along the wage distribution, which is the focus of this paper.

\footnotetext{
${ }^{6}$ Also Gould (2007) carries out a structural analysis showing that cities offer a wage premium only to white-collar workers. For an in-depth survey on urban wage premium and human capital externalities see Halfdanarson et al. (2010) and Puga (2010).
} 


\section{Institutional Setting and Data Description}

Italy is generally conceived as a fairly immobile country. Actually, the Italian labour market is much more mobile than usually thought. Italian job flows are higher than those of most European countries (Gomez-Salvator et al., 2004), and wage differentials and inequalities are rather high, and increasing along the period considered (OECD, 2011). As far as the Italian wage setting is concerned, since the beginning of the nineties there is a two-level wage bargaining system. The first level concerns a national collective bargaining, which has to preserve the purchasing power of wages at the sector level by incorporating at least partially- expected inflation rate in wage increases, while the second level of bargaining (either at the regional or firm level) allows rent sharing through performancerelated pay schemes at the region/firm level (see Cappellari et al., 2012, for a description of the Italian institution setting).

As for the data, we use a panel version of the Italian administrative database provided by INPS and elaborated by ISFOL (the Italian Institute for the Development of Vocational Training). ${ }^{7}$ It is an employer-employee dataset, constructed for the period 1986-2003 by merging the INPS employee information with the INPS employer information database. The units of the analysis are industrial- (manufacturing and mining) and servicedependent workers, both part-time (converted into full-time equivalent) and full-time. We focus on standard labour contracts, including both blue and white collars. Moreover, we take into account prime-age male workers, as in Glaeser and Maré (2001) and Mion and Naticchioni (2009), among others. In particular, we focus on individuals aged between 25

\footnotetext{
7 The sample scheme of the database follows individuals born on the $10^{\text {th }}$ of March, June, September and December and therefore the proportion of this sample in the Italian employee population is approximately of $1 / 90$. The panel version was constructed considering only one observation per year for each worker. For those workers who have more than one observation per year we selected the longest contract in terms of weeks worked. We also eliminated the observations below (above) the $0.5^{\text {th }}\left(99.5^{\text {th }}\right)$ percentile of the wage distribution.
} 
and 49 (when they first enter the database). ${ }^{8}$ We consider only those workers that are in the dataset for at least three years, in order to get more reliable within estimations. ${ }^{9}$ By doing so, we eventually have an unbalanced panel of 49,526 workers for 463,247 observations. As for worker characteristics, the database contains individual information such as age, gender, occupation, workplace, worker status (part-time or full-time), real gross yearly wage and the number of months, weeks and days worked. For firms, we have the plant location (province), the size (number of employees), and the sector.

Using INPS provincial data on industrial and service employment for the period 19862003, we can define the employment density, which represents the proxy for urban agglomeration. It is defined as in Combes (2000), Mion and Naticchioni (2009), Matano and Naticchioni (2012) and De Blasio and Di Addario (2005): employment in province $p$ at time $t$ out of the province area in square $\mathrm{km}$. The spatial breakdown is hence given by the province (provincia), classified in 95 units. ${ }^{10}$

We define the following groups in order to classify workers' movements: migrants from lower to higher density provinces, i.e. workers who move to a province with higher density with respect to the one they come from; migrants from higher to lower density provinces, i.e. workers who move to a province with lower density with respect to the one

\footnotetext{
${ }^{8}$ We do not consider, as standard in this literature (Topel, 1991), women and older workers since their wage dynamics is also affected by non-economic factors.

${ }^{9}$ In particular, in our sample we consider only workers with observations continuously available, i.e. available for consecutive years, since if data are missing for some years it is not possible to establish the patterns of worker's career dynamics. Moreover, we do not consider observations for migrants before and after ten years from migration, since we claim that ten years are a sufficient time span to investigate the wage dynamics before and after the migration. Hence, observations for migrants are considered when they remain at least three consecutive years in the dataset and for a maximum of ten years before/ after the migration.

10 The Italian provinces follow the European NUTS3 classification. We make use of 95 provinces, which was the number of provinces in the first year of analysis (1986). In recent years the number of provinces has risen to 103. Therefore, we reclassified the individuals belonging to the new provinces into the corresponding initial 95-province classification. Note that Italian provinces are more than administrative areas, and that they have to be thought as functional aggregates, encompassing local labour markets. From an historical point of view, Italian provinces can be related to the Italian Renaissance period, characterized by many flourishing cities and the accompanying surrounding areas.
} 
they come from; stayers, defined as workers who never change province. ${ }^{11}$ To provide a spatial characterization of stayers, we split this group into stayers in high density provinces (HD) and stayers in low density provinces (LD) on the basis of the (time average) median value of the density, computed on individual observations. ${ }^{12}$

Table 1 shows the descriptive statistics for the different workers' groups. As expected, the average wage of stayers is lower in LD provinces, while the average wage for migrants is close to those of stayers in HD provinces. Migrants are also generally slightly younger and are relatively more concentrated in white collar occupations, as stayers in HD provinces. Further, migrants from lower to higher density provinces as well as stayers in HD provinces work in larger firms. Finally, migrants and stayers in HD provinces are relatively more concentrated in the service sector, while greater representation in the industry sector is found for stayers in LD provinces.

[table 1 around here]

\footnotetext{
11 This definition of movers implies that each movement across cities is classified as a movement toward a higher or lower density province, with respect to the province of departure. This is to overcome arbitrary spatial definition of high/low density areas and to allow flexibility in the definition of the migration patterns. Nonetheless, we have also carried out the same analysis using a dichotomic spatial classification (low and high density provinces according to the -time average- median of density computed on individual observations) where we define as migrants only those workers moving from a low (high) to a high (low) density province. Results are robust to this change in the definition of movers (see estimates in Matano and Naticchioni, 2013).

12 Note that if an individual moves more than once between different sized provinces, he/she may "score" more than once in the analysis. We do not consider workers moving three or more times between different sized provinces, who in any case account for a very small fraction of the workers in the sample.
} 


\section{Empirical Analysis}

\subsection{The Extent of the Wage Level and the Wage Growth Effect along the Wage}

\section{Distribution}

We use a quantile regression approach to investigate the role of the wage level and the wage growth effect in determining the urban wage premium along the wage distribution. ${ }^{13}$ Following Glaeser and Maré (2001), we estimate a wage quantile regression with dummies that capture the exact path of migration:

$Q_{\theta}\left(\ln \left(w_{i, t}\right) / X_{i, t}\right)=\alpha_{\theta}+B_{\theta}^{\prime} * I_{-}$Char $_{i, t}+\beta_{\theta}^{*}$ Firmsize $_{i, t}+\sum_{j=1}^{T_{i}} \gamma_{j, \theta}^{l-h} I_{j, t}^{l-h}+\sum_{j=1}^{T_{i}} \gamma_{j, \theta}^{h-l} I_{j, t}^{h-l}+\varphi_{s, \theta}+\lambda_{r, \theta}+\delta_{t, \theta}$

where $\theta$ refers to the percentile, $i$ to individuals, $s$ to sectors, $r$ to regions, $t$ to time and $j$ stands for the dummies concerning year intervals before ("10 to 5 ", “4 to 3 ”, " 2 to 1 ”), after (" 1 to 2 ", "3 to 4 ", "5 to 10 ") and for the migration year (" 0 ")), with $j \in T_{i}$ is the individual time span. The superscripts $l-h$ stands for migrants from lower to higher density provinces, while $h$ - $l$ stands for migrants from higher to lower density provinces.

The dependent variable in our regressions is the (log) real gross weekly wage in euro. Wages have been deflated using the national Consumer Price Index (FOI index, Indice dei Prezzi al Consumo per le Famiglie di Operai e Impiegati, ISTAT). The base year is 2002. We do not apply cost of living adjustments for two main reasons. ${ }^{14}$ First, because we are interested in the firms' willingness to pay higher wages and not in the location choice of workers. Second, because Baum-Snow and Pavan (2012) show that using wages not deflated by cost of living does not prove a major problem when working with differenced data. In our

\footnotetext{
${ }^{13}$ For an in depth discussion of methodological issues concerning the identification of the urban premium see Combes et al. (2011).

14 Note also that regional/provincial cost of living indexes are not available in Italy. The Italian National Statistical Institute (ISTAT) only provides provincial (NUTS-3) inflation rates, without providing information on provincial price levels.
} 
analysis this consideration applies since we work with deviations from within individual average. As for the variables of interest, $I_{j, t}^{l-h}$ (with $\left.j=(-10-5, \ldots,+5-+10)\right)$ stands for a dummy variable that takes on a value of one when the worker, at time $t$, moved (will move) $j$ years before (after) from a lower to a higher density province, while $I_{j, t}^{h-l}$ stands for a dummy variable that takes on a value of one if the worker, at time $t$, moved (will move) $j$ years before (after) from a higher to a lower density province. Hence, the estimates of $\gamma_{j}^{l-h}$ and $\gamma_{j}^{h-t}$ reflect the dynamics of wages before or after a move.

As for the other variables, the term I_Char ${ }_{i, t}$ is a set of observed individual characteristics (age, age squared, blue collar dummy) and Firmsize $e_{i, t}$ is the proxy for firm heterogeneity, ${ }^{15}$ while $\varphi_{s}, \lambda_{r}, \delta_{t}$ are sector, region (NUTS2 level) and time dummies respectively. We carry out estimates for the $10^{\text {th }}, 25^{\text {th }}, 50^{\text {th }}, 75^{\text {th }}$ and $90^{\text {th }}$ percentiles.

Table 2 shows the cross sectional quantile regression results. The omitted category is 'stayers in LD provinces'. We also provide the coefficients for the stayers in HD provinces. It is worth noting that stayers in HD provinces earn significantly more than stayers in LD provinces. This confirms that the bulk of wage differences across the space dimension is also due to stayers, as emphasized by Mion and Naticchioni (2009). Moreover, the urban wage premium for stayers in HD provinces with respect to those in LD provinces increases along the wage distribution, ranging from $1.5 \%$ at the bottom of the wage distribution to $4.4 \%$ at the top. This means that skilled workers have a greater advantage in working in HD areas, in line with Matano and Naticchioni (2012).

Let us now move on to the analysis of the groups of migrants, starting from the migrants from lower to higher density provinces. It is interesting to note that using quantile regressions allows for better characterization of the wage dynamics of migrants,

15 We proxy the firm heterogeneity using the firm size, since firm productivity and wages are positively related with firm size (Postel-Vinay and Robin, 2006). 
both before and after migration. More specifically, from table 2 it emerges that skilled workers, at the $90^{\text {th }}$ percentile, experience a wage increase even before migration, suggesting that the sample of migrants at the $90^{\text {th }}$ percentile is positively selected with respect to stayers in LD provinces, consistent with the intuitions of Borjas (1987). On the contrary, migrants at the $10^{\text {th }}$ percentile represent a negative selection of the reference group of workers, since they experience a wage loss just (1-2 years) before migration. For workers at the median, instead, the wage dynamics just before migration is only slightly higher than that of the workers remaining in LD provinces. These findings suggests that unskilled workers mainly decide to migrate to a dense region after a negative shock in their current job, while for skilled workers the migration to dense regions is a tool to improve their already increasing wage dynamics.

As for the extent of the wage level and wage growth effect along the wage distribution, we begin with some considerations on the analysis of average wages, derived by using Ordinary Least Square. It may be noted that the wage level effect - the difference in wages within a year after the migration with respect to 1-2 years before the migration- is negligible $(0.1 \%)$ while the greatest part of the wage increase occurs after migration: the wage growth effect amounts to $8.6 \%(12.1 \%$ minus $3.5 \%)$. These findings are consistent with those of Glaeser and Maré (2001), who emphasize the importance of the wage growth effect.

Similar patterns are derived when considering the median, and this is hardly surprising since the distribution of the dependent variable, i.e. the log weekly wage, should come fairly close to a symmetric distribution. In particular, it emerges that at the median the entire wage premium arises essentially some years after migration, since the wage level effect is even negative but negligible $(-0.3 \%)$. 
Different and more interesting findings are derived when the tails of the wage distribution are taken into account. On the one hand, for workers at the bottom of the wage distribution $\left(10^{\text {th }}\right.$ percentile) there is a slight negative wage level effect $(-1.1 \%$, from $-2.4 \%$ to $-3.5 \%)$. Nonetheless, in the years following migration wages tend to rise and after 3-4 years these workers earn significantly more than unskilled workers in LD provinces $(+3.8 \%)$; the premium increases further after $5-10$ years $(+5.1 \%)$. This is in line with the wage growth hypothesis.

In the case of skilled workers (90th wage percentile) the pattern is different. In fact, the wage level effect is positive and amounts to a $1.5 \%$ (from $5.4 \%$ to $6.9 \%$ ). This finding suggests that for skilled workers agglomeration economies play a role in determining the urban wage premium. At the same time, there is evidence of a significant wage growth effect since the urban wage premium tends to increase over time ( $16.2 \%$ after $5-10$ years). ${ }^{16}$

As for the migration from higher to lower density provinces, it is noteworthy that, regardless of the wage percentile considered, there is no evidence of wage losses just after migration relative to 1-2 years before, consistent with the wage growth hypothesis and in line with Glaeser and Maré (2001). Rather, there is even a slight increase (1-2\%).

[table 2 around here]

However, these estimates might be biased since they do not take into account the role of the sorting of workers. Actually, part of the wage premium imputed to agglomeration economies, as well as human capital accumulation and quality matching, could be due to

\footnotetext{
16 Adding up the wage level effect (difference between coefficients just after the migration and 1-2 years before) and the wage growth effect (difference between coefficients after 5-10 years and just after the migration), it comes out that the total increase in wages is of $7.5 \%$ for workers at the 10 th percentile, $6.8 \%$ for workers at the $50^{\text {th }}$ percentile and $10.8 \%$ for workers at the $90^{\text {th }}$ percentile.
} 
the sorting of skilled workers into cities. In order to tackle this issue, we perform fixed effects estimates that allow controlling for individual unobserved heterogeneity (Combes et al., 2008, Mion and Naticchioni, 2009, Matano and Naticchioni, 2012).

Since we work in a quantile setting, we make use of the quantile fixed effects methodology proposed by Canay (2011). ${ }^{17}$ The omitted category within each group of migrants is that of ' $5-10$ years before the migration'.

The results in table 3 confirm that sorting matters. In particular, considering the migrants from lower to higher density provinces, the difference in coefficients between 510 years after the migration and 1-2 years before the migration generally decreases relative to previous estimates, and the reduction is greater at the highest percentiles, in line with Matano and Naticchioni (2012).

In terms of decomposition between the wage growth and wage level effect, for the median and the mean the results differ little from previous ones, i.e. the wage level effect remains quite small (around 1\%) and most of the wage increase occurs over time: the wage growth effect is equal to $3.9 \%$ at the median (5.0\% minus $1.1 \%$ just after migration) and $5.5 \%$ at the mean $(6.1 \%$ minus $0.6 \%)$.

Similarly, for low skilled workers the wage premium is essentially due to a wage growth effect: there is an increase immediately after migration $(+0.9 \%$, from $-4.7 \%$ to $3.8 \%)$, while most of the urban wage premium emerges over time $(+7.7 \%$, from $-3.8 \%$ to $3.9 \%)$.

Different and indeed interesting patterns emerge for skilled workers (at the $90^{\text {th }}$ percentile), since the urban wage premium is quite equally shared between the wage level effect $(2.3 \%$, from $3.5 \%$ to $5.8 \%)$, and the wage growth effect $(2.8 \%$, from $5.8 \%$ to $8.6 \%)$.

\footnotetext{
17 We have also run the same estimates using the procedure suggested by Koenker (2004). The results are very similar. They are available upon request. For interested readers, a detailed explanation of the implementation of the Canay methodology can be found in Matano and Naticchioni (2012).
} 
As for the migrants from higher to lower density provinces, fixed effects estimates generally confirm the cross sectional results. In particular there is no evidence of wage losses just after migration -relative to 1-2 years before migration- (in line with the wage growth hypothesis). ${ }^{18}$

These findings suggest that while for unskilled workers the determinants of the urban wage premium appear to be due mainly to a wage growth effect, and hence to the coordination and/or learning explanation, for skilled workers the urban wage premium is more uniformly distributed between the wage level and the wage growth effects.

[table 3 around here]

\subsection{The role of dynamic gain}

So far we have looked at the role of the wage growth and wage level effect in determining the urban wage premium along the wage distribution controlling for the sorting of workers. However, fixed effects estimates may be biased when dynamic gains related to experience in dense provinces are not taken into account (De la Roca and Puga, 2013). To take this issue on board, we introduce in the estimation different experience variables, defined according to where experience has been acquired. However, the experience variable is not collected in the sample of prime age workers of our dataset, i.e. we do not know when individuals started their working career. ${ }^{19}$ Therefore, we consider the sample of young workers (aged between 15-30) starting their first employment spell after January

\footnotetext{
${ }^{18}$ Note that also workers who move from higher to lower density provinces in general experience a wage increase, especially over time. This suggests that at least a part of the wage dynamics might be driven by migration choices. However, the magnitude of these wage increases is generally lower than the one generated when moving to a denser area, suggesting the existence of an urban wage premium due to spillovers generated in locations characterized by denser economic activity.

${ }^{19}$ This is mainly due to the fact that the data lack the information concerning the specific time period the individual entered the labour market.
} 
1986, for whom we can compute the experience variable within the sample. ${ }^{20}$ As a check, table 4 replicates for the group of young workers the fixed effects estimates derived on the group of prime-age workers (table 3). Results do not differ much, suggesting that the group of young workers displays similar spatial trends with respect to the one of prime age workers. ${ }^{21}$ In particular, trends of wage level and wage growth effects are the same, while in terms of magnitude estimates on young workers display slightly higher values for the $10^{\text {th }}$ and $50^{\text {th }}$ percentile and slightly lower for the $90^{\text {th }}$ percentile.

[table 4 around here]

Using the sample of young workers, we introduce in the econometric specification the standard experience variable and two additional variables: the experience acquired in the two biggest Italian cities (Rome and Milan), and the experience acquired in the following four biggest Italian cities in terms of population (Palermo, Genoa, Turin and Naples). Table 5 shows the results for young workers when introducing the detailed experience variables. First of all, it is worth noting that along the whole wage distribution all experience variables have a positive impact on wages, although the negative quadratic coefficient highlights the presence of diminishing marginal returns. To ease the interpretation we comment the linear coefficients. As for general experience, there is a declining impact along the wage distribution, from $5.3 \%$ at the $10^{\text {th }}$ percentile to $2.2 \%$ at the $90^{\text {th }}$ percentile. This

\footnotetext{
${ }^{20}$ We cannot keep individuals recorded in the database as working from January 1986, since the formal beginning of all these jobs in the INPS database is forced to be January 1986. Note also that for the sample of young workers we assume that those individuals entering the sample did not previously had any working experience as self-employed or in the public sector. This seems to be plausible, since self-employed and public sector spells are less likely when young.

${ }^{21}$ Note that in the estimates of table 4 we put experience instead of age, since the two variables (in levels) are collinear in fixed effects estimates. Therefore, results can be compared with the ones related to prime age workers (table 3).
} 
suggests that unskilled workers benefit the most from experience in the labour market. However, experience acquired in Rome and Milan has a positive and increasing impact along the wage distribution. In particular, the returns to experience acquired in Rome and Milan range from $1.7 \%$ at the $10^{\text {th }}$ percentile to $2.2 \%$ at the $90^{\text {th }}$ percentile. As for the experience acquired in the other four main Italian provinces, magnitudes are lower but still increasing along the wage distribution (from $0.6 \%$ at the $10^{\text {th }}$ percentile to $1.0 \%$ at the $90^{\text {th }}$ percentile). The increasing trends for experience acquired in the two and four top cities mitigate the decreasing trend observed for the standard experience variable. Still the overall returns to experience, considering both linear and quadratic coefficients, are decreasing: for a worker who spent five years in Rome (or Milan) at the $10^{\text {th }}$ percentile the overall returns are equal to $27.5 \%$ while at the $90^{\text {th }}$ percentile are equal to $19.5 \%$. The differences among percentiles would have been anyway greater without introducing the experience acquired in top cities.

[table 5 around here]

As for migration patterns, it is interesting to note that the introduction of experience variables only slightly affects the wage level effect, which is now equal to $0.3 \%, 0.8 \%$ and $1.6 \%$ at the $10^{\text {th }}, 50^{\text {th }}$ and $90^{\text {th }}$ percentile respectively. As for the wage growth effect, there is a general decrease, being now equal to $8.2 \%, 3.4 \%$ and $0.9 \%$ at the $10^{\text {th }}, 50^{\text {th }}$ and $90^{\text {th }}$ percentile respectively. Moreover, the reduction in the wage growth effect affects more the upper tail of the wage distribution, i.e. the decrease is around $60 \%$ at the $90^{\text {th }}$ percentile, $28 \%$ at the $50^{\text {th }}$ percentile and just $10 \%$ at the $10^{\text {th }}$ percentile. This means that experience 
acquired in top cities catches up part of the wage dynamics previously captured by migration dummies. 2223

\subsection{Focus on the Wage Growth Effect: Disentangling the "Learning" and the}

\section{"Coordination" Effects along the Wage Distribution}

One of the findings of our paper is that a non-negligible part of the urban wage premium is related to a wage growth effect, consistent with Glaeser and Maré (2001). As stressed in the literature, the wage growth effect could be the outcome of either faster human capital accumulation (learning) or more efficient job searching and matching (coordination). Our aim in this section is to disentangle the roles of the "learning" and "coordination" effects.

We focus on the sample of migrants from lower to higher density provinces, once they have moved into a higher density province. We include variables that are considered in the literature as proxy for the within-job wage growth (tenure, using a quadratic specification) and for the between-jobs wage growth (dummy for job change, as in Baum-Snow and Pavan, 2012). We estimate the following wage quantile regression:

$$
\begin{aligned}
& Q_{\theta}\left(\ln \left(w_{i, t}\right) / X_{i, t}\right)=\alpha_{\theta}+B_{\theta}^{\prime} * I_{-} \text {Char }_{i, t}+\beta_{\theta} * \text { Firmsize }_{i, t}+\gamma_{1, \theta} * \text { Tenure }_{i, t}+\gamma_{2, \theta} * \text { TenureSq }_{i, t}+\gamma_{3, \theta} * \text { JobChange }_{i, t}+ \\
& +\phi_{s, \theta}+\delta_{t, \theta}
\end{aligned}
$$

where as before $\theta$ refers to the percentile, $i$ to individuals, $s$ to sectors, $t$ to time.

\footnotetext{
22 De la Roca and Puga (2013) extend their approach by introducing interaction terms between the years of experience acquired by workers in main cities and the locations where the workers are currently employed. Their results show that these interactions are either not significant or small in magnitude, i.e. the value of experience is fully portable across cities. We have also run a robustness check introducing interaction terms between the experience acquired in main Italian cities and being currently employed in other (smaller or greater) provinces. Results show that our baseline estimates are not affected by the introduction of these interaction terms. Further, the impact of these interaction terms differ depending on the wage percentile considered. For the median and the average, estimates are consistent with those of De la Roca and Puga (2013), since they are either not significant or small in magnitude. Instead, in the lower and upper tail of the distribution, there are some significant effects, which suggest an interesting heterogeneity in dynamic gains across the wage distribution. These estimates are available upon request.

23 We have also carried out a wide set of robustness checks concerning the following issues: unobserved location heterogeneity; different measures of skills; a different spatial classification; the endogeneity of migration; long stay migrants; endogeneity of firm size. Results confirm main findings. We do not include these checks in the paper for sake of synthesis. The interested reader can refer to the section "Robustness check" in Matano and Naticchioni (2013).
} 
The dependent variable is again the (log) real gross weekly wage in euro. The variables of interest are Tenure $_{i, t}$, Tenure squared $_{i, t}$-that capture firm specific human capital accumulation-, and the dummy Job Change $e_{i, t}$ that takes the value of one when a worker changes job in the corresponding year. ${ }^{24}$ All the other variables are the same as in the previous section. In table 6 we set out the estimates derived by means of the quantile fixed effect regression to control for the sorting of workers.

The results show that the impact of within- and between-jobs components on wages is not uniform along the wage distribution. In fact, the unskilled workers' wage growth $\left(10^{\text {th }}\right.$ $25^{\text {th }}$ wage percentiles) is due mainly to positive -marginally diminishing - returns to tenure, suggesting that firm specific human capital accumulation plays a substantial role. For instance an unskilled worker $\left(10^{\text {th }} / 25^{\text {th }}\right.$ percentile) who has moved to a higher density area gets a wage increase of $2.5 \% / 0.5 \%$ after 5 years spent in the same firm. Further, the linear coefficient of the returns to tenure decreases along the wage distribution, becoming negative at the $90^{\text {th }}$ percentile, even if the quadratic term switches to positive. This suggests that for skilled workers job tenure plays only a minor role.

As for the impact of job changes, this is positive for skilled workers $\left(75^{\text {th }}\right.$ and $90^{\text {th }}$ percentile), suggesting better matching opportunities in dense area, consistent with Wheeler (2006). Returns to job changes are instead negative for unskilled workers. ${ }^{25}$

\footnotetext{
${ }^{24}$ In our data it is not possible to identify firms belonging to the same financial group. Further, in some cases different establishments within the same firm might have different social security codes as they were different firms. For this reason, we cannot address interesting issues such as intra-firm and intra-group mobility.

${ }^{25}$ In the sample there is no information on whether the workers' job changes are voluntary. One might actually argue that not controlling for this issue might affect our estimates. For this reason, we have run a robustness check defining as voluntary those job changes characterized by an unemployment spell between the old and the new job lower or equal to two months. Hence, non-voluntary job changes are those with unemployment spells longer than two months. When carrying out the same econometric estimation for the two groups of movers, voluntary vs non voluntary, results interestingly show that penalties at the lowest percentiles are driven by a negative impact of non-voluntary job changes, while at the highest percentile the impact is mainly driven by voluntary job changes. Since the chosen definition of voluntary job change is arbitrary, we do not put too much emphasis on these estimates, which are anyway available upon request.
} 
Combining these findings, it clearly emerges that in dense areas unskilled workers advance in their careers by remaining in their jobs, while skilled workers benefit by exploiting matching opportunities. ${ }^{26}$

[table 6 around here]

However, one might argue that the sample of migrants from lower to higher density provinces is not representative of the whole economy (Mion and Naticchioni, 2009, BaumSnow and Pavan, 2012). For this reason, we carry out the same econometric specification including tenure and job change dummies- on the sample of stayers using the dichotomic classification of LD and HD, i.e. stayers in the sense that they remain in the same LD or HD area although they may change jobs within the area. Since the results derived from the sample of stayers are very similar to those derived from the group of migrants (table 7), our findings may well be taken as representative of the whole economy. ${ }^{27} 28$

[table 7 around here]

Moreover, we also verify whether there is a higher incidence of job changes in HD provinces, as argued in Yankow (2006), which would entail a greater cumulative wage growth. On the evidence of table 8 the overall job change incidence can be seen to be

\footnotetext{
${ }^{26}$ We have run the same estimates using the sample of young workers and introducing the detailed experience variables, as in table 5. Results are very close from a qualitatively point of view. They are available upon request.

${ }^{27}$ Estimates for tenure in tables 6 and 7 can actually change sign after some years (around 7-10) from the migration, due to the quadratic term. Nonetheless this change concerns a relatively few number of observations in the sample (around 1.2\%), thus suggesting that this issue should not represent a main concern of the analysis.

28 There might be some degree of interaction between tenure and the job change dummy. For this reason, we have run the same estimates for migrants including one at a time the tenure and the job change variable; results remain consistent and are available upon request.
} 
basically the same for the group of stayers in LD provinces $(9 \%)$ and for the group of stayers in HD provinces $(8.8 \%)$, and a similar incidence is observed for the group of migrants from lower to higher density provinces after migration (8.5\%). However, since we work in a quantile framework we aim at enriching the analysis of Yankow (2006) by investigating whether the differences between different sized provinces in the incidence of job changes vary along the wage distribution. To do so we compute the incidence of job changes for the four quartiles of the wage distribution.

From table 8 it emerges that for the first three quartiles of the wage distribution there are decidedly negligible differences in the incidence of job changes between the groups of stayers in LD provinces and the stayers in HD provinces. Interestingly, in the first quartile the incidence of job changes for migrants is almost two percentage points higher than for stayers. Since for this group returns to job changes are negative, this entails a stronger cumulative penalization for low skilled workers due to job mobility.

Further, it is interesting to note that at the fourth quartile the incidence of job changes for the group of stayers in high density provinces $(7.5 \%)$ is higher than for the group of stayers in low density provinces $(6.5 \%)$, while an intermediate values is observed for the group of migrants $(7.1 \%)$. This evidence points out that skilled workers have a higher incidence of job change in HD provinces than in LD provinces. This also means that for skilled workers not only are the returns to each single job change higher in HD provinces (tables 6 and 7) but also the incidence of job changes, suggesting that the cumulative returns to job changes are even higher than those shown in tables 6 and 7.

[table 8 around here] 
All these findings suggest that for skilled workers the driving force of wage growth dynamics in dense areas is largely a matter of better matching opportunities, while for unskilled workers it is related to human capital accumulation, in line with the learning explanation. ${ }^{29}$

\section{Conclusions}

In this paper we investigate whether, and if so to what extent, the determinants of the urban wage premium, in terms of agglomeration economies, human capital accumulation and quality matching, differ along the wage distribution. Having controlled for the sorting of workers by means of quantile fixed effect regressions, we arrive at the following findings.

First, the patterns of the urban wage premium are far from homogeneous along the wage distribution. In particular, skilled workers enjoy wage premiums that are balanced between a wage level effect at the time of migration and a wage growth effect. For low skilled workers the urban wage premium is due to a wage growth effect, since wages increase over time.

Our findings are robust to control for experience acquired in bigger cities, in line with recent literature (De la Roca and Puga, 2013). Interestingly, we also show that while

\footnotetext{
29 Our findings are to some extent not consistent with those derived by Baum-Snow and Pavan (2012). However, the two papers differ for many aspects such as the sample, the econometric approach and the countries analysed, among others. To make the two approaches more comparable, we carry out a robustness check for the sample of prime age workers, using the age variable, proxy for experience in the labour market. In particular, we use a specification including the linear term of age separated for workers in LD and HD provinces, and the quadratic term in common between LD and HD provinces, as in Baum-Snow and Pavan (2012) for the experience variable. In the specification we also include the job change dummies and all the covariates of table 7 (excluding tenure). When focusing on the conditional mean, the results come closer to Baum-Snow and Pavan (2012), i.e. the coordination explanation plays a very negligible role. However, when considering the two tails of the distribution our findings are still confirmed: skilled workers benefit more from job changes while unskilled workers benefit more from human capital accumulation. These estimates are available upon request.
} 
experience displays decreasing returns along the wage distribution, experience acquired in top cities (Rome and Milan) is associated to increasing returns along the distribution.

Second, we further investigate the determinants of the wage growth effect in dense areas. For both migrants to higher density provinces and stayers in LD and HD provinces, within-job wage growth is an important driver of the wage growth effect for unskilled workers, and this effect is stronger in HD provinces: unskilled workers benefit more from human capital accumulation in dense areas. On the contrary, for skilled workers it is more the between-jobs wage growth that matters and this effect is stronger in HD provinces: in dense areas there are better matching opportunities for skilled workers. 


\section{References}

Baum-Snow, Nathaniel and Ronni Pavan. 2012. "Understanding the City Size Wage Gap", The Review of Economic Studies, 79(1), 88-127.

Borjas, George J. 1987. "Self-selection and earnings of immigrants", American Economic Review, $77,531-53$.

Canay, Ivan. 2011. "A Simple Approach to Quantile Regression for Panel Data", The Econometrics Journal, 14 (3), 368-386.

Cappellari, Lorenzo, Carlo Dell'Aringa, and Marco Leonardi. 2012. "Temporary Employment, Job Flows and Productivity: A Tale of Two Reforms," Economic Journal, Royal Economic Society, 122(562), F188-F215.

Ciccone, Antonio and Robert E. Hall. 1996. "Productivity and the Density of Economic Activity", American Economic Review, 86, 54-70.

Combes, Pierre-Philippe. 2000. "Economic structure and local growth: France, 1984-1993", Journal of Urban Economics, 47, 329-355.

Combes, Pierre-Philippe, Gilles Duranton, and Laurent Gobillon. 2008. "Spatial Wage Disparities: Sorting Matters!", Journal of Urban Economics, 63, 723-742.

Combes, Pierre-Philippe, Gilles Duranton, and Laurent Gobillon. 2011. "The identification of agglomeration economies", Journal of Economic Geography, 11, 253-266.

Combes, Pierre-Philippe, Gilles Duranton, Laurent Gobillon, and Sébastien Roux. 2012. "Sorting and local wage and skill distributions in France", Regional Science and Urban Economics, 42, 913-930.

De la Roca, Jorge and Diego Puga. 2013. Learning by Working in Big Cities, CEMFI Working Paper 2013_1301.

De Blasio, Guido and Sabrina Di Addario. 2005. “Do Workers Benefit from Industrial Agglomeration?", Journal of Regional Science, 45(4), 797-827.

Glaeser, Edward L. 1998. “Are cities dying?”, Journal of Economic Perspectives, 12, 139-160.

Glaeser, Edward L. 1999. “Learning in cities”, Journal of Urban Economics, 46, 254-277.

Glaeser, Edward.L. and David C. Maré. 2001. "Cities and Skills", Journal of Labor Economics, 19(2), 316-342.

Glaeser, Edward.L. and Matthew G.Resseger. 2010. “The Complementarity Between Cities and Skills", Journal of Regional Science, 50(1), 221-244.

Gomez-Salvador, Ramon, Julian Messina, and Giovanna Vallanti. 2004. “Gross Job Flows and Institutions in Europe", Labour Economics, 11, 469-485.

Gould, Eric D. 2007. “Cities, Workers, and Wages: A Structural Analysis of the Urban Wage Premium" Review of Economic Studies, 74, 477-506.

Hanson, Gordon H. 2005. "Market potential, increasing returns and geographic concentration", Journal of International Economics, 67(1), 1-24. 
Helsley Robert W. and William C. Strange. 1990. "Matching and agglomeration economies in a system of cities", Regional Science and Urban Economics, 28, 189-212.

Halfdanarson, Benedikt, Daniel F. Heuermann, and Jens Sudekum. 2010. "Human Capital Externalities and the Urban Wage Premium: two Literatures and their Interrelations", Urban Studies, 47(4), 749-767.

Kim, Sunwoong. 1987. "Diversity in urban labor markets and agglomeration economies", Papers of the Regional Science Association, 62, 57-70.

Kim, Sunwoong. 1990. "Labor heterogeneity, wage bargaining, and agglomeration economies", Journal of Urban Economics, 28, 160-177.

Koenker, Roger. 2004. "Quantile Regression for Longitudinal Data", Journal of Multivariate Analysis, 91(1), 74-89.

Lehmer Florian and Joachim Möller. 2010. “Interrelations between the urban wage premium and firm-size wage differentials: a microdata cohort analysis for Germany", The Annals of Regional Science, 45(1), 31-53.

Matano, Alessia and Paolo Naticchioni. 2012. "Wage Distribution and the Spatial Sorting of Workers", Journal of Economic Geography, vol.12(2), 379-408.

Matano, Alessia and Paolo Naticchioni. 2013. "What Drives the Urban Wage Premium? Evidence along the Wage Distribution", IZA Discussion Paper 7811.

Mion, Giordano and Paolo Naticchioni. 2009. "The Spatial Sorting and Matching of Skills and Firms", Canadian Journal of Economics, Canadian Economics Association, 42(1), 28-55.

Möller, Joachim and Anette Haas. 2003. “The Agglomeration Differential Reconsidered: an investigation with German Micro Data 1984-1997". In J. Broecker, D. Dhose, R. Soltwedel (eds) Innovation Clusters and Interregional Competition, Berlin: Springer.

Moretti, Enrico. 2004. "Human Capital Externalities in Cities", in Henderson J.V. and Thisse J.F. (eds.), Handbook of Regional and Urban Economics, Elsevier-North Holland, Amsterdam, 4.

OECD (2011), “Divided We Stand: Why Inequality Keeps Rising”, OECD Publishing.

Postel-Vinay, Fabien and Jean-Marc Robin. 2006. “Microeconometric Search-Matching Models and Matched Employer-Employee Data", in R. Blundell, W. Newey and T. Persson (eds.), Advances in Economics and Econometrics: Theory and Applications, Ninth World Congress, 2, Cambridge: Cambridge University Press.

Puga, Diego. 2010. “The magnitude and causes of agglomeration economies", Journal of Regional Science, 50(1), 203-219.

Topel, Robert. 1991. "Specific capital, mobility, and wages: Wages rise with job seniority", Journal of Political Economy, 99, 145-176.

Wheeler, Christopher H. 2004. "Wage inequality and urban density", Journal of Economic Geography, 4, 412-437.

Wheeler, Christopher H. 2006. "Cities and the growth of wages among young workers: Evidence from the NLSY", Journal of Urban Economics, 60(2), 162-184. 
Yankow, Jeffrey J. 2006. "Why do cities pay more? An empirical examination of some competing theories of the urban wage premium", Journal of Urban Economics 60(2), 139-161. 
Tables

\begin{tabular}{|c|c|c|c|c|c|c|c|c|}
\hline \multirow[b]{2}{*}{ Variables } & \multicolumn{4}{|c|}{ Stayers Low Density $(179,431)$} & \multicolumn{4}{|c|}{ Stayers High Density $(197,125)$} \\
\hline & Mean & Std.Dev. & Min & $\operatorname{Max}$ & Mean & Std.Dev. & Min & $\operatorname{Max}$ \\
\hline Real Weekly Wage (log) & 6.00 & 0.38 & 4.25 & 8.73 & 6.14 & 0.42 & 4.25 & 9.23 \\
\hline Age & 42.05 & 8.06 & 25 & 66 & 42.47 & 8.06 & 25 & 67 \\
\hline Blue Collar & 0.71 & 0.45 & 0 & 1 & 0.58 & 0.49 & 0 & 1 \\
\hline White Collar & 0.29 & 0.45 & 0 & 1 & 0.42 & 0.49 & 0 & 1 \\
\hline Firm Size (log) & 4.60 & 2.69 & 0 & 12.11 & 5.25 & 2.80 & 0 & 12.11 \\
\hline North West & 0.23 & 0.42 & 0 & 1 & 0.51 & 0.50 & 0 & 1 \\
\hline North East & 0.25 & 0.43 & 0 & 1 & 0.23 & 0.42 & 0 & 1 \\
\hline Centre & 0.21 & 0.40 & 0 & 1 & 0.19 & 0.39 & 0 & 1 \\
\hline South & 0.22 & 0.41 & 0 & 1 & 0.07 & 0.26 & 0 & 1 \\
\hline Island & 0.11 & 0.31 & 0 & 1 & 0.00 & 0.00 & 0 & 0 \\
\hline Industry & 0.66 & 0.47 & 0 & 1 & 0.59 & 0.49 & 0 & 1 \\
\hline \multirow[t]{2}{*}{ Services } & 0.34 & 0.47 & 0 & 1 & 0.41 & 0.49 & 0 & 1 \\
\hline & \multicolumn{4}{|c|}{ Migrants Low-High Density $(43,130)$} & \multicolumn{4}{|c|}{ Migrants High-Low Density $(43,561)$} \\
\hline Variables & Mean & Std.Dev. & Min & $\operatorname{Max}$ & Mean & Std.Dev. & Min & Max \\
\hline Real Weekly Wage (log) & 6.16 & 0.49 & 4.27 & 8.87 & 6.16 & 0.50 & 4.25 & 9.04 \\
\hline Age & 40.56 & 7.81 & 25 & 65 & 40.62 & 7.93 & 25 & 67 \\
\hline Blue Collar & 0.52 & 0.50 & 0 & 1 & 0.52 & 0.50 & 0 & 1 \\
\hline White Collar & 0.48 & 0.50 & 0 & 1 & 0.48 & 0.50 & 0 & 1 \\
\hline Firm Size (log) & 5.25 & 2.66 & 0 & 12.07 & 5.15 & 2.54 & 0 & 12.11 \\
\hline North West & 0.35 & 0.48 & 0 & 1 & 0.36 & 0.48 & 0 & 1 \\
\hline North East & 0.25 & 0.43 & 0 & 1 & 0.25 & 0.43 & 0 & 1 \\
\hline Centre & 0.20 & 0.40 & 0 & 1 & 0.18 & 0.38 & 0 & 1 \\
\hline South & 0.14 & 0.35 & 0 & 1 & 0.15 & 0.36 & 0 & 1 \\
\hline Island & 0.06 & 0.25 & 0 & 1 & 0.06 & 0.24 & 0 & 1 \\
\hline Industry & 0.59 & 0.49 & 0 & 1 & 0.60 & 0.49 & 0 & 1 \\
\hline Services & 0.41 & 0.49 & 0 & 1 & 0.40 & 0.49 & 0 & 1 \\
\hline
\end{tabular}

Source: Panel INPS (processed by ISFOL) data. Number of observations in brackets. 


\begin{tabular}{|c|c|c|c|c|c|c|}
\hline & q10 & $\mathrm{q} 25$ & q50 & q75 & q90 & mean \\
\hline \multirow[t]{2}{*}{ Stayer in a High Density province } & $0.015^{* * *}$ & $0.015^{* * *}$ & $0.026^{* * *}$ & $0.036^{* * *}$ & $0.044^{* * *}$ & $0.032^{* * *}$ \\
\hline & {$[0.002]$} & {$[0.001]$} & [0.001] & {$[0.002]$} & {$[0.002]$} & {$[0.001]$} \\
\hline \multicolumn{7}{|c|}{ Moving to a province of higher density: } \\
\hline \multirow[t]{2}{*}{ Observed 5-10 years before a move } & $0.036^{\text {*** }}$ & $0.030^{* * *}$ & $0.030^{* * *}$ & $0.030^{* * *}$ & $0.043^{* * *}$ & $0.050^{* * *}$ \\
\hline & {$[0.004]$} & {$[0.004]$} & {$[0.003]$} & {$[0.005]$} & {$[0.010]$} & {$[0.004]$} \\
\hline \multirow[t]{2}{*}{ Observed 3-4 years before a move } & $0.017^{* * *}$ & $0.021^{* * *}$ & $0.031^{* * *}$ & $0.045^{\star * *}$ & $0.057^{* * *}$ & $0.053^{* * *}$ \\
\hline & {$[0.006]$} & {$[0.004]$} & [0.005] & {$[0.005]$} & [0.007] & {$[0.004]$} \\
\hline \multirow[t]{2}{*}{ Observed 1-2 years before a move } & $-0.024^{\star * *}$ & 0.004 & $0.018^{* * *}$ & $0.036^{* * *}$ & $0.054^{* * *}$ & $0.034^{* * *}$ \\
\hline & {$[0.007]$} & {$[0.003]$} & {$[0.002]$} & [0.003] & {$[0.006]$} & {$[0.003]$} \\
\hline \multirow[t]{2}{*}{ Observed within a year after a move } & $-0.035^{* * *}$ & -0.008 & $0.015^{* * *}$ & $0.041^{* * *}$ & $0.069^{* * *}$ & $0.035^{* * *}$ \\
\hline & {$[0.007]$} & {$[0.005]$} & {$[0.004]$} & {$[0.006]$} & {$[0.011]$} & {$[0.004]$} \\
\hline \multirow[t]{2}{*}{ Observed 1-2 years after a move } & 0.007 & $0.016^{* * *}$ & $0.041^{* * *}$ & $0.076^{* * *}$ & $0.105^{\star * *}$ & $0.073^{* * *}$ \\
\hline & {$[0.005]$} & {$[0.005]$} & [0.003] & {$[0.006]$} & {$[0.008]$} & {$[0.004]$} \\
\hline \multirow[t]{2}{*}{ Observed 3-4 years after a move } & $0.038^{* * *}$ & $0.041^{* * *}$ & $0.060^{* * *}$ & $0.099^{* * *}$ & $0.137^{* * *}$ & $0.099^{* * *}$ \\
\hline & {$[0.004]$} & {$[0.005]$} & {$[0.007]$} & {$[0.008]$} & {$[0.015]$} & {$[0.005]$} \\
\hline \multirow[t]{2}{*}{ Observed 5-10 years after a move } & $0.051^{* * *}$ & $0.054^{* * *}$ & $0.086^{* * *}$ & $0.125^{\star * *}$ & $0.162^{* * *}$ & $0.121^{* * *}$ \\
\hline & {$[0.005]$} & {$[0.004]$} & {$[0.005]$} & [0.008] & {$[0.010]$} & {$[0.004]$} \\
\hline \multicolumn{7}{|l|}{ Moving to a province of lower density: } \\
\hline \multirow[t]{2}{*}{ Observed 5-10 years before a move } & $0.029^{* * *}$ & $0.029^{* * *}$ & $0.037^{* * *}$ & $0.050^{* * *}$ & $0.072^{\star * *}$ & $0.054^{* * *}$ \\
\hline & {$[0.005]$} & {$[0.004]$} & {$[0.004]$} & {$[0.005]$} & {$[0.008]$} & {$[0.004]$} \\
\hline \multirow[t]{2}{*}{ Observed 3-4 years before a move } & $0.008^{*}$ & $0.013^{* * *}$ & $0.036^{* * *}$ & $0.049^{* * *}$ & $0.067^{* * *}$ & $0.049^{* * *}$ \\
\hline & {$[0.005]$} & {$[0.004]$} & {$[0.005]$} & {$[0.005]$} & {$[0.010]$} & {$[0.004]$} \\
\hline \multirow[t]{2}{*}{ Observed $1-2$ years before a move } & $-0.047^{* * *}$ & $-0.010^{* *}$ & $0.017^{* * *}$ & $0.039^{* * *}$ & $0.066^{* * *}$ & $0.025^{* * *}$ \\
\hline & {$[0.006]$} & {$[0.004]$} & {$[0.004]$} & {$[0.005]$} & {$[0.008]$} & {$[0.003]$} \\
\hline \multirow[t]{2}{*}{ Observed within a year after a move } & $-0.028^{* * *}$ & 0.003 & $0.031^{* * *}$ & $0.062^{* * *}$ & $0.086^{* * *}$ & $0.052^{* * *}$ \\
\hline & {$[0.007]$} & {$[0.004]$} & {$[0.003]$} & {$[0.005]$} & {$[0.008]$} & {$[0.004]$} \\
\hline \multirow[t]{2}{*}{ Observed 1-2 years after a move } & 0.005 & $0.022^{* * *}$ & $0.044^{* * *}$ & $0.078^{* * *}$ & $0.103^{* * *}$ & $0.074^{* * *}$ \\
\hline & {$[0.005]$} & {$[0.005]$} & {$[0.004]$} & {$[0.007]$} & [0.007] & {$[0.004]$} \\
\hline \multirow[t]{2}{*}{ Observed 3-4 years after a move } & $0.034^{* * *}$ & $0.042^{* * *}$ & $0.059^{* * *}$ & $0.095^{\star * *}$ & $0.126^{* * *}$ & $0.094^{* * *}$ \\
\hline & {$[0.007]$} & {$[0.006]$} & {$[0.003]$} & {$[0.007]$} & {$[0.011]$} & {$[0.005]$} \\
\hline \multirow[t]{2}{*}{ Observed $5-10$ years after a move } & $0.045^{* * *}$ & $0.054^{* * *}$ & $0.063^{* * *}$ & $0.093^{* * *}$ & $0.131^{* * *}$ & $0.096^{* * *}$ \\
\hline & {$[0.007]$} & {$[0.003]$} & {$[0.004]$} & {$[0.008]$} & {$[0.008]$} & {$[0.004]$} \\
\hline N. of Observations & 463,247 & 463,247 & 463,247 & 463,247 & 463,247 & 463,247 \\
\hline N. of Individuals & 49,526 & 49,526 & 49,526 & 49,526 & 49,526 & 49,526 \\
\hline
\end{tabular}


Table 3: Wage Dynamics of Migrants. Quantile Fixed Effects Regression (Canay, 2011).

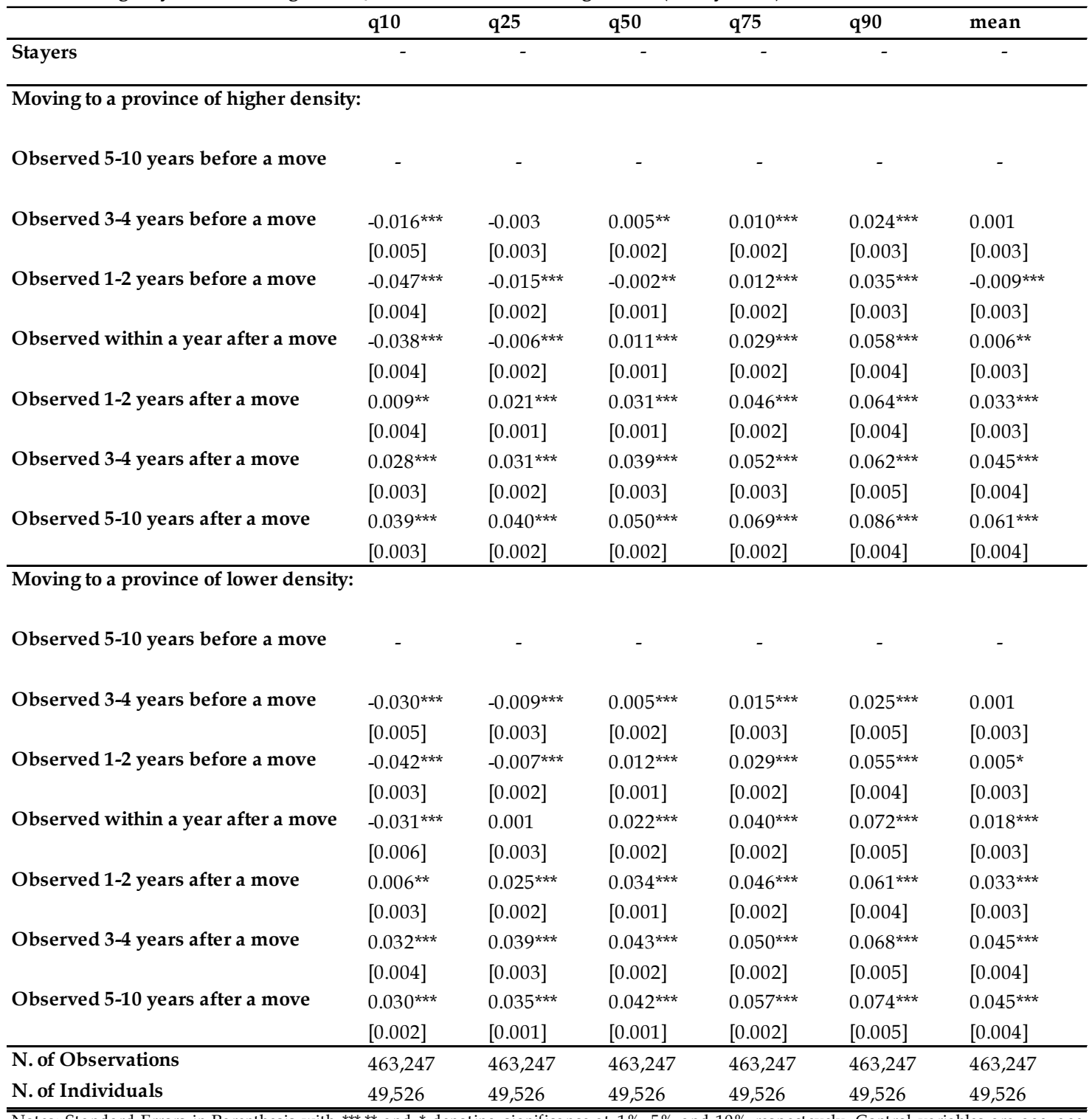

Notes: Standard Errors in Parenthesis with ${ }^{* * *},{ }^{* *}$ and ${ }^{*}$ denoting significance at $1 \%, 5 \%$ and $10 \%$ respectevely. Control variables are age, age squared, occupation dummies, firm size and regional, sector and time dummies. 


\begin{tabular}{|c|c|c|c|c|c|c|}
\hline & q10 & $q 25$ & q50 & q75 & q90 & mean \\
\hline \multirow[t]{2}{*}{ Experience } & $0.057^{* * *}$ & $0.045^{\star * *}$ & $0.038^{* * *}$ & $0.032^{* * *}$ & $0.026^{* * *}$ & $0.041^{* * *}$ \\
\hline & {$[0.000]$} & {$[0.000]$} & {$[0.000]$} & {$[0.000]$} & {$[0.000]$} & {$[0.000]$} \\
\hline \multirow[t]{2}{*}{ Experience squared $^{\dagger}$} & $-0.187^{* * *}$ & $-0.132^{* * *}$ & $-0.089^{* * *}$ & $-0.055^{\star * *}$ & $-0.017^{* * *}$ & $-0.102^{* * *}$ \\
\hline & {$[0.003]$} & {$[0.002]$} & {$[0.001]$} & {$[0.002]$} & {$[0.003]$} & {$[0.002]$} \\
\hline \multicolumn{7}{|l|}{ Moving to a province of higher density: } \\
\hline Observed 5-10 years before a move & - & - & - & - & - & - \\
\hline \multirow[t]{2}{*}{ Observed $3-4$ years before a move } & $-0.024^{* * *}$ & $-0.013^{* * *}$ & 0.002 & $0.015^{* * *}$ & $0.027^{* * *}$ & 0.000 \\
\hline & {$[0.006]$} & {$[0.003]$} & {$[0.003]$} & {$[0.003]$} & {$[0.003]$} & {$[0.004]$} \\
\hline \multirow[t]{2}{*}{ Observed 1-2 years before a move } & $-0.056^{* * *}$ & $-0.019^{* * *}$ & $0.004^{* *}$ & $0.026^{* * *}$ & $0.045^{\star * *}$ & -0.003 \\
\hline & {$[0.004]$} & {$[0.002]$} & {$[0.002]$} & [0.003] & {$[0.002]$} & {$[0.004]$} \\
\hline \multirow[t]{2}{*}{ Observed within a year after a move } & $-0.047^{* * *}$ & $-0.009^{* * *}$ & $0.016^{* * *}$ & $0.037^{* * *}$ & $0.064^{* * *}$ & $0.011^{* *}$ \\
\hline & {$[0.006]$} & {$[0.003]$} & {$[0.002]$} & {$[0.003]$} & {$[0.005]$} & {$[0.004]$} \\
\hline \multirow[t]{2}{*}{ Observed 1-2 years after a move } & $0.008^{* *}$ & $0.024^{\star * *}$ & $0.037^{* * *}$ & $0.049^{* * *}$ & $0.071^{* * *}$ & $0.037^{* * *}$ \\
\hline & {$[0.003]$} & {$[0.002]$} & {$[0.001]$} & {$[0.002]$} & {$[0.003]$} & {$[0.004]$} \\
\hline \multirow[t]{2}{*}{ Observed 3-4 years after a move } & $0.036^{* * *}$ & $0.046^{* * *}$ & $0.052^{* * *}$ & $0.062^{* * *}$ & $0.069^{* * *}$ & $0.052^{* * *}$ \\
\hline & {$[0.005]$} & {$[0.003]$} & {$[0.002]$} & {$[0.003]$} & {$[0.004]$} & {$[0.005]$} \\
\hline \multirow[t]{2}{*}{ Observed 5-10 years after a move } & $0.045^{\star * *}$ & $0.053^{\star * *}$ & $0.063^{* * *}$ & $0.073^{* * *}$ & $0.087^{* * *}$ & $0.067^{* * *}$ \\
\hline & {$[0.004]$} & {$[0.002]$} & {$[0.002]$} & {$[0.002]$} & {$[0.006]$} & {$[0.005]$} \\
\hline \multicolumn{7}{|l|}{ Moving to a province of lower density: } \\
\hline Observed 5-10 years before a move & - & - & - & - & - & - \\
\hline \multirow[t]{2}{*}{ Observed $3-4$ years before a move } & $-0.018^{* * *}$ & $-0.010^{* * *}$ & 0.003 & $0.013^{* * *}$ & $0.030^{\star * *}$ & 0.004 \\
\hline & {$[0.005]$} & {$[0.002]$} & {$[0.002]$} & {$[0.002]$} & {$[0.006]$} & {$[0.004]$} \\
\hline \multirow[t]{2}{*}{ Observed 1-2 years before a move } & $-0.051^{* * *}$ & $-0.020^{* * *}$ & 0.001 & $0.025^{* * *}$ & $0.055^{\star * *}$ & -0.003 \\
\hline & {$[0.003]$} & {$[0.001]$} & {$[0.002]$} & {$[0.003]$} & {$[0.004]$} & {$[0.004]$} \\
\hline \multirow[t]{2}{*}{ Observed within a year after a move } & $-0.055^{* * *}$ & $-0.018^{* * *}$ & $0.008^{* * *}$ & $0.030^{* * *}$ & $0.055^{\star * *}$ & 0.001 \\
\hline & {$[0.006]$} & {$[0.003]$} & {$[0.002]$} & {$[0.003]$} & {$[0.003]$} & {$[0.004]$} \\
\hline \multirow[t]{2}{*}{ Observed 1-2 years after a move } & $-0.005^{\star *}$ & $0.012^{* * *}$ & $0.024^{* * *}$ & $0.035^{* * *}$ & $0.049^{* * *}$ & $0.020 * * *$ \\
\hline & {$[0.002]$} & {$[0.002]$} & {$[0.002]$} & {$[0.002]$} & {$[0.003]$} & {$[0.004]$} \\
\hline \multirow[t]{2}{*}{ Observed $3-4$ years after a move } & $0.013^{* *}$ & $0.026^{* * *}$ & $0.034^{* * *}$ & $0.039^{* * *}$ & $0.049^{* * *}$ & $0.030^{* * *}$ \\
\hline & {$[0.006]$} & {$[0.002]$} & {$[0.002]$} & {$[0.003]$} & {$[0.006]$} & {$[0.005]$} \\
\hline \multirow[t]{2}{*}{ Observed 5-10 years after a move } & $0.016^{* * *}$ & $0.029^{* * *}$ & $0.038^{* * *}$ & $0.050^{* * *}$ & $0.066^{* * *}$ & $0.038^{* * *}$ \\
\hline & {$[0.006]$} & {$[0.002]$} & {$[0.002]$} & {$[0.004]$} & {$[0.004]$} & {$[0.005]$} \\
\hline N. of Observations & 286,258 & 286,258 & 286,258 & 286,258 & 286,258 & 286,258 \\
\hline N. of Individuals & 36,077 & 36,077 & 36,077 & 36,077 & 36,077 & 36,077 \\
\hline
\end{tabular}


Table 5: Wage Dynamics of Migrants. Sample of Young Workers (15-30). Detailed Experience. Quantile Fixed Effects Regression.

\begin{tabular}{|c|c|c|c|c|c|c|}
\hline & $\mathrm{q} 10$ & q25 & q50 & q75 & q90 & mean \\
\hline \multirow[t]{2}{*}{ Experience } & $0.053^{* * *}$ & $0.042^{* * *}$ & $0.034^{* * *}$ & $0.029^{* * *}$ & $0.022^{* * *}$ & $0.037^{* * *}$ \\
\hline & {$[0.001]$} & {$[0.000]$} & {$[0.000]$} & {$[0.000]$} & {$[0.001]$} & {$[0.000]$} \\
\hline \multirow[t]{2}{*}{ Experience squared $^{\dagger}$} & $-0.173^{* * *}$ & $-0.120^{* * *}$ & $-0.075^{* * *}$ & $-0.042^{* * *}$ & 0.001 & $-0.088^{* * *}$ \\
\hline & {$[0.003]$} & {$[0.002]$} & [0.001] & {$[0.002]$} & {$[0.004]$} & {$[0.001]$} \\
\hline \multirow[t]{2}{*}{ Experience in Rome and Milan } & $0.017^{* * *}$ & $0.018^{* * *}$ & $0.020^{* * *}$ & $0.021^{* * *}$ & $0.022^{* * *}$ & $0.020^{* * *}$ \\
\hline & {$[0.001]$} & {$[0.000]$} & {$[0.000]$} & {$[0.000]$} & {$[0.000]$} & {$[0.001]$} \\
\hline \multirow[t]{2}{*}{ Experience squared (Rome and Milan) ${ }^{\dagger}$} & $-0.058^{* * *}$ & $-0.065^{* * *}$ & $-0.073^{* * *}$ & $-0.074^{* * *}$ & $-0.073^{* * *}$ & $-0.071^{* * *}$ \\
\hline & {$[0.005]$} & {$[0.003]$} & {$[0.003]$} & {$[0.004]$} & {$[0.003]$} & [0.005] \\
\hline \multirow[t]{2}{*}{ Experience in other 4 major provinces of Italy } & $0.006^{* * *}$ & $0.006^{* * *}$ & $0.006^{* * *}$ & $0.007^{* * *}$ & $0.010^{* * *}$ & $0.007^{* * *}$ \\
\hline & {$[0.001]$} & {$[0.000]$} & {$[0.000]$} & {$[0.000]$} & {$[0.001]$} & {$[0.001]$} \\
\hline Experience squared in other 4 major provinces & $-0.022 * * *$ & $-0.022^{* * *}$ & $-0.026^{* * *}$ & $-0.030 * * *$ & $-0.051^{* * *}$ & $-0.029 * * *$ \\
\hline of Italy $^{\dagger}$ & {$[0.006]$} & {$[0.004]$} & {$[0.003]$} & {$[0.004]$} & {$[0.008]$} & {$[0.006]$} \\
\hline \multicolumn{7}{|l|}{ Moving to a province of higher density: } \\
\hline Observed 5-10 years before a move & - & - & - & - & - & - \\
\hline \multirow[t]{2}{*}{ Observed 3-4 years before a move } & $-0.020^{* * *}$ & $-0.009^{* *}$ & $0.006^{* *}$ & $0.019^{* * *}$ & $0.031^{* * *}$ & 0.005 \\
\hline & {$[0.006]$} & {$[0.004]$} & {$[0.003]$} & {$[0.003]$} & {$[0.003]$} & {$[0.004]$} \\
\hline \multirow[t]{2}{*}{ Observed $1-2$ years before a move } & $-0.047^{* * *}$ & $-0.012^{* * *}$ & $0.011^{* * *}$ & $0.032^{* * *}$ & $0.053^{* * *}$ & 0.004 \\
\hline & {$[0.004]$} & {$[0.002]$} & {$[0.002]$} & {$[0.002]$} & {$[0.005]$} & {$[0.004]$} \\
\hline \multirow[t]{2}{*}{ Observed within a year after a move } & $-0.044^{* * *}$ & -0.003 & $0.019^{* * *}$ & $0.040^{* * *}$ & $0.069^{* * *}$ & $0.015^{* * *}$ \\
\hline & {$[0.008]$} & {$[0.004]$} & {$[0.002]$} & {$[0.002]$} & {$[0.004]$} & {$[0.004]$} \\
\hline \multirow[t]{2}{*}{ Observed 1-2 years after a move } & $0.008^{*}$ & $0.025^{* * *}$ & $0.037^{* * *}$ & $0.050^{* * *}$ & $0.070^{* * *}$ & $0.038^{* * *}$ \\
\hline & {$[0.004]$} & {$[0.003]$} & {$[0.002]$} & {$[0.003]$} & {$[0.004]$} & [0.004] \\
\hline \multirow[t]{2}{*}{ Observed $3-4$ years after a move } & $0.034^{* * *}$ & $0.043^{* * *}$ & $0.049^{* * *}$ & $0.058^{* * *}$ & $0.068^{* * *}$ & $0.049^{* * *}$ \\
\hline & {$[0.005]$} & {$[0.002]$} & {$[0.002]$} & {$[0.003]$} & {$[0.004]$} & {$[0.005]$} \\
\hline \multirow[t]{2}{*}{ Observed 5-10 years after a move } & $0.038^{* * *}$ & $0.045^{\star * *}$ & $0.053^{* * *}$ & $0.066^{* * *}$ & $0.078^{* * *}$ & $0.058^{* * *}$ \\
\hline & {$[0.003]$} & {$[0.003]$} & [0.003] & {$[0.003]$} & {$[0.004]$} & [0.005] \\
\hline \multicolumn{7}{|l|}{ Moving to a province of lower density: } \\
\hline Observed 5-10 years before a move & - & - & - & - & - & - \\
\hline \multirow[t]{2}{*}{ Observed 3-4 years before a move } & $-0.023^{* * *}$ & $-0.017^{* * *}$ & -0.003 & $0.006^{* *}$ & $0.023^{* * *}$ & -0.002 \\
\hline & {$[0.004]$} & {$[0.003]$} & {$[0.002]$} & {$[0.003]$} & {$[0.005]$} & {$[0.004]$} \\
\hline \multirow[t]{2}{*}{ Observed $1-2$ years before a move } & $-0.062^{* * *}$ & $-0.031^{* * *}$ & $-0.011^{* * *}$ & $0.013^{* * *}$ & $0.043^{* * *}$ & $-0.015^{* * *}$ \\
\hline & {$[0.004]$} & {$[0.002]$} & [0.002] & {$[0.002]$} & {$[0.003]$} & {$[0.004]$} \\
\hline \multirow[t]{2}{*}{ Observed within a year after a move } & $-0.064^{* * *}$ & $-0.030^{* * *}$ & -0.003 & $0.019^{* * *}$ & $0.044^{* * *}$ & $-0.010^{* *}$ \\
\hline & {$[0.006]$} & {$[0.004]$} & [0.003] & {$[0.003]$} & {$[0.005]$} & {$[0.004]$} \\
\hline \multirow[t]{2}{*}{ Observed 1-2 years after a move } & $-0.014^{* * *}$ & 0.003 & $0.015^{* * *}$ & $0.025^{* * *}$ & $0.039^{* * *}$ & $0.011^{* *}$ \\
\hline & {$[0.003]$} & {$[0.002]$} & {$[0.002]$} & {$[0.002]$} & {$[0.005]$} & {$[0.004]$} \\
\hline \multirow[t]{2}{*}{ Observed 3-4 years after a move } & 0.008 & $0.020^{* * *}$ & $0.027^{* * *}$ & $0.032^{* * *}$ & $0.042^{* * *}$ & $0.024^{* * *}$ \\
\hline & {$[0.006]$} & {$[0.002]$} & {$[0.002]$} & {$[0.002]$} & {$[0.005]$} & {$[0.005]$} \\
\hline \multirow[t]{2}{*}{ Observed 5-10 years after a move } & $0.012^{* * *}$ & $0.026^{* * *}$ & $0.034^{* * *}$ & $0.046^{* * *}$ & $0.062^{* * *}$ & $0.036^{* * *}$ \\
\hline & {$[0.004]$} & {$[0.002]$} & {$[0.003]$} & {$[0.003]$} & {$[0.004]$} & [0.005] \\
\hline N. of Observations & 286,258 & 286,258 & 286,258 & 286,258 & 286,258 & 286,258 \\
\hline N. of Individuals & 36,077 & 36,077 & 36,077 & 36,077 & 36,077 & 36,077 \\
\hline
\end{tabular}




\begin{tabular}{|c|c|c|c|c|c|c|}
\hline \multicolumn{7}{|c|}{$\begin{array}{l}\text { Table 6: Returns to Tenure and to Job Changes. Sample of Migra } \\
\text { Provinces after the Migration. Quantile Fixed Effects Regressions. }\end{array}$} \\
\hline & q10 & $\mathrm{q} 25$ & q50 & q75 & q90 & Mean \\
\hline \multirow[t]{2}{*}{ Job Change } & $-0.031^{* * *}$ & $-0.020^{* * *}$ & -0.005 & $0.013^{* * *}$ & $0.024^{* * *}$ & -0.003 \\
\hline & {$[0.009]$} & {$[0.004]$} & {$[0.004]$} & {$[0.004]$} & {$[0.008]$} & {$[0.005]$} \\
\hline \multirow[t]{2}{*}{ Tenure } & $0.015^{* * *}$ & $0.006^{* * *}$ & $0.002^{* *}$ & -0.002 & $-0.006^{* *}$ & $0.003^{*}$ \\
\hline & {$[0.002]$} & {$[0.001]$} & {$[0.001]$} & {$[0.002]$} & {$[0.002]$} & {$[0.002]$} \\
\hline \multirow[t]{2}{*}{ Tenure squared $^{\dagger}$} & $-0.163^{* * *}$ & $-0.091^{* * *}$ & $-0.030^{* *}$ & $0.042^{* *}$ & $0.096^{* * *}$ & -0.026 \\
\hline & {$[0.002]$} & {$[0.010]$} & {$[0.012]$} & {$[0.019]$} & {$[0.027]$} & {$[0.018]$} \\
\hline \multirow[t]{2}{*}{ Age } & $0.075^{* * *}$ & $0.068^{* * *}$ & $0.067^{* * *}$ & $0.064^{* * *}$ & $0.061^{* * *}$ & $0.069^{* * *}$ \\
\hline & {$[0.003]$} & {$[0.001]$} & {$[0.001]$} & {$[0.001]$} & {$[0.002]$} & {$[0.003]$} \\
\hline \multirow[t]{2}{*}{ Age squared } & $-0.001^{* * *}$ & $-0.001^{* * *}$ & $-0.001^{* * *}$ & $-0.001^{* * *}$ & $-0.000^{* * *}$ & $-0.001^{* * *}$ \\
\hline & {$[0.000]$} & {$[0.000]$} & {$[0.000]$} & {$[0.000]$} & {$[0.000]$} & {$[0.000]$} \\
\hline \multirow[t]{2}{*}{ Firm size } & $0.013^{* * *}$ & $0.012^{* * *}$ & $0.012^{* * *}$ & $0.011^{* * *}$ & $0.010^{* * *}$ & $0.012^{* * *}$ \\
\hline & {$[0.001]$} & {$[0.000]$} & {$[0.000]$} & {$[0.000]$} & {$[0.001]$} & {$[0.002]$} \\
\hline \multirow[t]{2}{*}{ Blue collar dummy } & $-0.060^{\star * *}$ & $-0.058^{* * *}$ & $-0.062^{* * *}$ & $-0.065^{* * *}$ & $-0.082^{* * *}$ & $-0.067^{* * *}$ \\
\hline & {$[0.004]$} & {$[0.002]$} & {$[0.001]$} & {$[0.002]$} & {$[0.004]$} & {$[0.014]$} \\
\hline \multirow[t]{2}{*}{ Constant } & $3.973^{* * *}$ & $4.230^{* * *}$ & $4.318^{* * *}$ & $4.473^{* * *}$ & $4.641^{* * *}$ & $4.328^{* * *}$ \\
\hline & {$[0.053]$} & {$[0.018]$} & {$[0.020]$} & {$[0.030]$} & {$[0.053]$} & {$[0.088]$} \\
\hline N. of Observations & 19,503 & 19,503 & 19,503 & 19,503 & 19,503 & 19,503 \\
\hline N. of Individuals & 4,003 & 4,003 & 4,003 & 4,003 & 4,003 & 4,003 \\
\hline
\end{tabular}

Notes: Standard Errors in Parenthesis with ${ }^{* * *, * *}$ and ${ }^{*}$ denoting significance at $1 \%, 5 \%$ and $10 \%$ respectevely. The other control variables are sector and time dummies.

${ }^{\dagger}$ Coefficients and standard errors of this variable are multiplied by 100 to ease the interpretation. 
Table 7: Returns to Tenure and to Job Changes in High (HD) and Low Density (LD) Provinces. Sample of Stayers. Quantile Fixed Effects Estimates.

\begin{tabular}{|c|c|c|c|c|c|c|}
\hline & q10 & $\mathrm{q} 25$ & q50 & q75 & $\mathrm{q} 90$ & mean \\
\hline \multirow[t]{2}{*}{ Job Change HD } & $-0.019 * * *$ & $-0.008^{* * *}$ & 0.002 & $0.019^{* * *}$ & $0.041^{* * *}$ & $0.007^{* * *}$ \\
\hline & {$[0.004]$} & {$[0.002]$} & {$[0.002]$} & {$[0.002]$} & {$[0.003]$} & {$[0.002]$} \\
\hline \multirow[t]{2}{*}{ Job Change LD } & $-0.034^{* * *}$ & $-0.021^{* * *}$ & $-0.010^{* * *}$ & 0.004 & $0.020 * * *$ & $-0.008^{* * *}$ \\
\hline & {$[0.004]$} & {$[0.003]$} & {$[0.002]$} & {$[0.002]$} & {$[0.005]$} & {$[0.002]$} \\
\hline \multirow[t]{2}{*}{ Tenure HD } & $0.019 * * *$ & $0.010^{* * *}$ & $0.005^{* * *}$ & $0.003^{* * *}$ & 0.001 & $0.009 * * *$ \\
\hline & {$[0.001]$} & {$[0.000]$} & {$[0.000]$} & {$[0.000]$} & {$[0.001]$} & {$[0.001]$} \\
\hline \multirow[t]{2}{*}{ Tenure squared $\mathrm{HD}^{\dagger}$} & $-0.145^{\star * *}$ & $-0.085^{\star * *}$ & $-0.046^{* * *}$ & $-0.017^{* * *}$ & 0.000 & $-0.071^{* * *}$ \\
\hline & {$[0.006]$} & {$[0.003]$} & {$[0.002]$} & {$[0.004]$} & {$[0.006]$} & {$[0.004]$} \\
\hline \multirow[t]{2}{*}{ Tenure LD } & $0.013^{* * *}$ & $0.005^{* * *}$ & 0.000 & $-0.003^{* * *}$ & $-0.007^{* * *}$ & $0.003^{* * *}$ \\
\hline & {$[0.001]$} & {$[0.000]$} & {$[0.000]$} & {$[0.000]$} & {$[0.001]$} & {$[0.001]$} \\
\hline \multirow[t]{2}{*}{ Tenure squared $\mathrm{LD}^{\dagger}$} & $-0.115^{\star * *}$ & $-0.065^{\star * *}$ & $-0.025^{\star * *}$ & 0.005 & 0.039 *** & $-0.042^{* * *}$ \\
\hline & {$[0.004]$} & [0.003] & [0.002] & {$[0.004]$} & [0.008] & {$[0.004]$} \\
\hline \multirow[t]{2}{*}{ Age } & $0.061^{* * *}$ & $0.055^{* * *}$ & $0.052^{* * *}$ & $0.049 * * *$ & $0.045^{\star * *}$ & $0.054^{* * *}$ \\
\hline & {$[0.000]$} & {$[0.000]$} & {$[0.000]$} & {$[0.000]$} & {$[0.001]$} & {$[0.001]$} \\
\hline \multirow[t]{2}{*}{ Age squared } & $-0.000^{* * *}$ & $-0.000^{* * *}$ & $-0.000 * * *$ & $-0.000^{* * *}$ & $-0.000^{* * *}$ & $-0.000 * * *$ \\
\hline & {$[0.000]$} & {$[0.000]$} & {$[0.000]$} & {$[0.000]$} & {$[0.000]$} & {$[0.000]$} \\
\hline \multirow[t]{2}{*}{ Firm size } & $0.017^{* * *}$ & $0.015^{\star * *}$ & $0.014^{* * *}$ & $0.014^{* * *}$ & $0.011^{* * *}$ & $0.014^{* * *}$ \\
\hline & {$[0.000]$} & {$[0.000]$} & {$[0.000]$} & {$[0.000]$} & {$[0.000]$} & {$[0.000]$} \\
\hline \multirow[t]{2}{*}{ Blue collar dummy } & $-0.070^{* * *}$ & $-0.073^{* * *}$ & $-0.076^{* * *}$ & $-0.083^{* * *}$ & $-0.099 * * *$ & $-0.083^{* * *}$ \\
\hline & {$[0.001]$} & [0.001] & {$[0.001]$} & {$[0.001]$} & {$[0.002]$} & {$[0.003]$} \\
\hline \multirow[t]{2}{*}{ Constant } & $4.210^{* * *}$ & $4.455^{* * *}$ & $4.593^{* * *}$ & $4.743^{* * *}$ & $4.941^{* * *}$ & $4.480 * * *$ \\
\hline & [0.007] & [0.006] & {$[0.006]$} & [0.010] & [0.016] & {$[0.020]$} \\
\hline N. of Observations & 190,386 & 190,386 & 190,386 & 190,386 & 190,386 & 190,386 \\
\hline N. of Individuals & 24,869 & 24,869 & 24,869 & 24,869 & 24,869 & 24,869 \\
\hline
\end{tabular}

Table 8: Incidence of Job Changes along the Quartiles of the Wage Distribution. Samples of Stayers in LD, Stayers in HD, and Migrants from Lower to Higher Density Provinces after the Migration.

\begin{tabular}{lccc}
\hline & Stayers in LD & Stayers in HD & $\begin{array}{c}\text { Migrants from lower to } \\
\text { higher density provinces }\end{array}$ \\
\hline Overall & 9.0 & 8.8 & 8.5 \\
\hline 1st quartile & 11.4 & 11.8 & 13.3 \\
2nd quartile & 8.7 & 8.5 & 8.2 \\
3rd quartile & 7.4 & 7.7 & 6.7 \\
4th quartile & 6.5 & 7.5 & 7.1 \\
\hline \hline
\end{tabular}

